\title{
Comparison of drug delivery systems: Nanotube and $p$-Sulphonatocalix[4]arene, by Density Functional Theory
}

\author{
Karim Zare ${ }^{1,2}$ and Nasim Shadmani ${ }^{3^{*}}$
}

\begin{abstract}
Nowadays, the use of calixarenes and nanotubes are widely spread in the field of drug delivery. In this work, interaction between $p$-sulphonatocalix[4]arene and nanotube $(6,6)$ with Fluorouracil drug is investigated. Density function theory (DFT) calculations have been performed using the Gauss view and Gaussian03 by B3LYP (beck three-parameter hybrid functional combined with Lee-Yang-Parr correlation functional) method and 6-31G (d) standard basis set. The length bond ( $\AA$ ), bond angel (degree), dihedral angel (in degree), hyperconjucation energy, and total energy $\left(\mathrm{KJ} \mathrm{mol}^{-1}\right)$, formation energy $\left(\mathrm{KJ} \mathrm{mol}^{-1}\right)$, moment dipole (in Debye) and occupancy of between nanotube $(6,6)$ and $p$-sulphonatocalix[4]arene with anti-cancer drug are calculated by B3LYP/6-31G (d) method. The results show that composite 2 is more stable than the other composite. The hyperconjucation energy $\left(E^{2}\right)$ in the $p$-sulphonatocalix[4]arene-fluorouracil is higher than that in the other composite. The standard formation energy $\left(\Delta \mathrm{E}_{f}^{\circ}\right)$ in the the $p$-sulphonatocalix[4]arene-fluorouracil is more negative value (lower) to composite 1.
\end{abstract}

Keyword: Single-walled carbon nanotube; DFT; 5-Fluoropyramidin-2; 4(1H, 3H)-dion; p-Sulphonatocalix[4]arene; Drug design; $\mathrm{NBO} ; \mathrm{C}_{\mathrm{v}}$, Energy stability

\section{Background}

The extensive research on carbon nanotube done to their structural characterization and discovered by Iijima in 1991 year [1,2]. Among the numerous delivery systems currently under investigations, single-walled carbon nanotubes seem to embody a promising option [3]. Single-walled carbon nanotubes are made up of carbon atoms arranged in a series of condensed benzene rings and wrapped into a tubular form (Figure 1b). Nanotubes are two types of: single- walled carbon nanotube (SWCNT) and multi-walled carbon nanotube (MWCNT), respelsitvly. In particular, the application of single-walled carbon nanotube, calixarene, fulouren and cytosine as new carrier for drug delivery, properties became doable soon after the demonstration of cellular uptake of this new material [4-10].

In the paper, the composite of nanotube $(6,6)$-fluorouracil and $p$-Sulphonato-calix[4]arene)-fluorouracil are

\footnotetext{
* Correspondence: n.shadmani@gmail.com

${ }^{3}$ Young Researchers and Elites Club, Rasht Branch, Islamic Azad University, Rasht, Iran

Full list of author information is available at the end of the article
}

investigated as a drug delivery system. Calixarenes are a group of supramolecule that have basket-like shape which are easily available through the cyclocondensation of para-substituted phenols with formaldehyde [11-15]. The $p$-Sulphonatocalx[4] arene have received considerable attention in recent years because of their selective metal ion binding properties in aqueous solution, the formation of basket- like be layer structures in the solid state, and the observation of $\mathrm{H}$-bonding with aromatic rim. Calixarenes invested in the context of electrochemical selective, sensor, stationary phases, solid phase extraction phases and drug delivery in five decade ago [16-20]. One way to increase the aqueous solubility of drugs is to use complexing agents to form hast- guest complex [21]. P-sulphonatocalix[4] arene are react with types of drugs, metals and other gust organic and inorganic from upper rim that inclusion $\mathrm{SO}_{3} \mathrm{H}$ group and lower rim that inclusion $\mathrm{OH}$ group is not reactivity. They have shown interesting properties of activity against bacteria, fungi, cancerous cells and enveloped viruses, but also against thrombosis or fibrosis diseases [22-25]. Anti-cancer drugs act in a dominant fashion: 


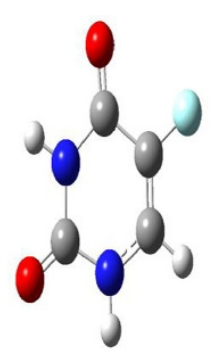

(a)

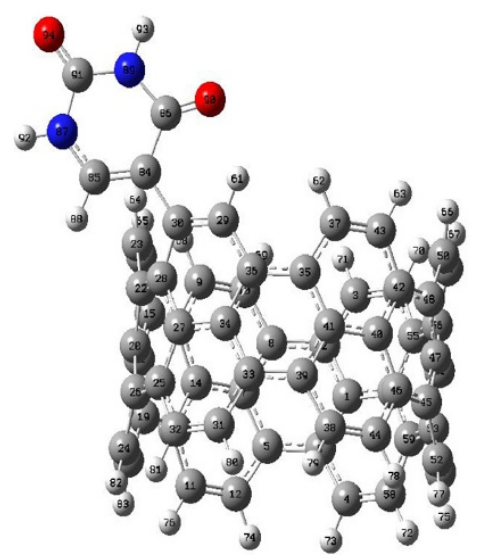

(d)

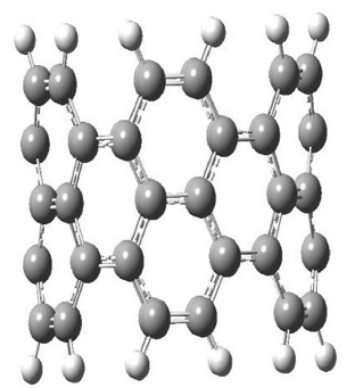

(b)

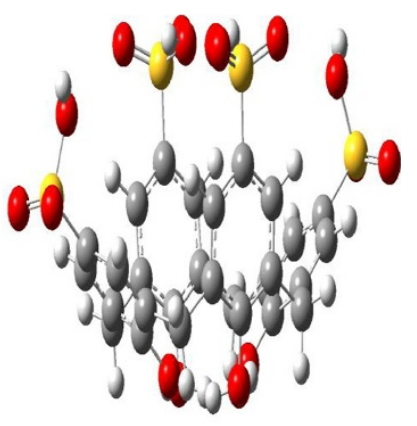

(c)

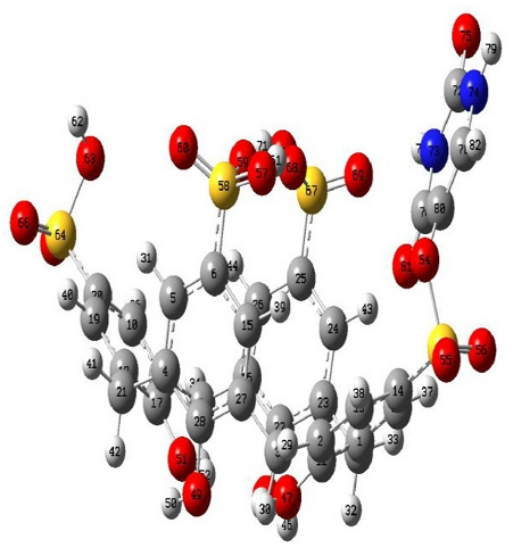

(e)

Figure 1 The structures of optimized molecular by B3LYP/6-31G (d) method at 298.15 K. (a) Fluorouracil, (b) Nanotube(6,6), (c) p-Sulphonatocalix[4]arene, (d) Composite1, (e) Composite 2.

when ectopically over expressed they specifically destroy tumor cells without harming normal cells. Anticancer genes have only recently emerged from studies on cancer cells [26,27]. Fluorouracil or 5-Fluoropyramidin-2, 4 $(1 \mathrm{H}, 3 \mathrm{H})$-dion is used as anti- cancer drug. Fluorouracil derived of pyrimidine that used as an anti-cancer drug for years ago. The structure of Fluorouracil is observed in Figure 1a. It is anti-metabolite drug and acts in several ways, but principally as synthesis inhibitor [28]. These days there are ways to deliver drug system in the body without side effects. In this paper, we reported types of drug delivery system like single-walled nanotube, p-Sulphonatocalix[4]arene.

\section{Results and discussion}

Density Functional Theory (DFT), hybrid QM/MM and Car-Parrinello molecular dynamics simulations can be used in theory investigation. The using computer for drug design and analized interaction between drug and receptors (for example: nanotube, fullerenes and calixarene) and give optimal fit [29-32]. The more detailed information on structure, charge distribution, and energetic of the base pair are study by DFT method. At present, quantum chemical is extensive applicable to the interpretation of physical and chemical properties of drugs. The cellular receptors of many drugs used for medical treatment are react with proteins. By binding to the receptor, drugs either enhance or inhibit its activity. The biological mechanism of a disease then often suggests the types of molecules needed for nanodrugs [33-35]. Figure 1a, b, c, d, e shows the optimized composites fluorouracil, nanotube(6,6), p-Sulphonatocalix [4]arene, and nanotube(6,6)-fluorouracil (composite1), p-Sulphonatocalix[4] arenes-fluorouracil (composite2), respectively, by DFT method at B3LYP/6-31G(d) level.

In Table 1, it is obvious that composite 2 has formed higher hyperconjugation energy than the composite 1 . Also, the results show by increasing $P$ share in hybrid of atoms, the occupancy decreases. The $S$ orbital share in hybrid of carbon in composite 2 is more than that in composite 1 . If combined with the most stable hyperconjugation energy, the occupancy coefficient becomes smaller. Composite 2 is more stable than the composite 1 . The hyperconjugation energy composite 2 
Table 1 Parameters of NBO analysis of composite 1 and 2 by B3LYP/6-31G (d) method at 298.15 K

\begin{tabular}{|c|c|c|c|c|c|c|c|}
\hline Agent & Donor & Occupancy & Acceptor & Occupancy & Hybrid & $\mathrm{E}^{2}$ & $\Sigma \mathrm{E}^{2}$ \\
\hline \multirow[t]{8}{*}{ Composite 1} & $\mathrm{BD}(1) \mathrm{C} 30-\mathrm{C} 84$ & 1.96631 & $\mathrm{BD}^{*}(1) \mathrm{C} 27-\mathrm{C} 28$ & 0.02586 & $\mathrm{SP}^{1.98}$ & 1.48 & \\
\hline & & & $B D^{*}(1) C 28-C 30$ & 0.02920 & $S p^{2.06}$ & 1.70 & \\
\hline & & & $B D^{*}(1) C 29-C 30$ & 0.02033 & $S p^{1.79}$ & 3.12 & \\
\hline & & & $B D^{*}(1) C 29-C 36$ & 0.02164 & $S P^{1.96}$ & 2.51 & \\
\hline & & & $B D^{*}(1) C 84-C 85$ & 0.01852 & $S P^{1.88}$ & 3.55 & 35.5 \\
\hline & & & $B D^{*}(1) C 84-C 86$ & 0.06682 & $S P^{2.28}$ & 1.82 & \\
\hline & $B D *(2) C 84-C 85$ & 0.23733 & $B D^{*}(1) C 85-N 87$ & 0.01939 & $S P^{2.51}$ & 3.76 & \\
\hline & & & $\mathrm{BD}^{*}(2) \mathrm{C} 29-\mathrm{C} 30$ & 0.2195 & SP99.99 & 17.59 & 3 \\
\hline \multirow[t]{8}{*}{ Composite 2} & $\mathrm{BD}(1) \mathrm{O} 54-\mathrm{C} 80$ & 1.98809 & $\mathrm{BD}^{*}(1) \mathrm{N} 73-\mathrm{C} 76$ & 0.07349 & $S P^{1.77}$ & 1.32 & \\
\hline & & & $B D^{*}(1) N 74-C 78$ & 0.01797 & $S P^{1.69}$ & 2.00 & \\
\hline & & & $B D^{*}(1) C 78-C 80$ & 0.02461 & $\mathrm{SP}^{1.58}$ & 1.19 & \\
\hline & LP(1)O54 & 1.95049 & $\mathrm{BD}^{*}(1) \mathrm{C} 78-\mathrm{C} 80$ & 0.024241 & $S P^{1.58}$ & 2.71 & \\
\hline & & & $B D^{*}(2) C 78-C 80$ & 0.024241 & SP 99.99 & 3.67 & 46.3 \\
\hline & LP(2)O54 & 1.90929 & $B D^{*}(1) C 76-C 80$ & 0.07057 & $S P^{1.72}$ & 8.76 & \\
\hline & & & $\mathrm{BD}^{*}(1) \mathrm{C} 78-\mathrm{C} 80$ & 0.02461 & $S P^{1.58}$ & 5.14 & \\
\hline & $\mathrm{BD}^{*}(2) \mathrm{C} 78-\mathrm{C} 80$ & 0.38376 & $\mathrm{BD}^{*}(1) \mathrm{S} 53-\mathrm{O} 54$ & 0.24241 & $S P^{4.81}$ & 21.57 & 9 \\
\hline
\end{tabular}

(46.39) is larger than that of composite1. If the $\mathrm{S}$ orbital hybrid of a compound is lower, the occupancy becomes larger. In composite 2, hybrid and occupancy are $S P^{99.99}$ and 0.024241 (acceptor) and 1.90929 (donor), respectively. For example, in composite 2, hybrid and occupancy are $S P^{4.81}$ and 0.24241 (acceptor) and 0.38278 (donor), respectively. In Table 1, the Mulliken charges of electronegative $\mathrm{O}_{84}$ donor atoms and $\mathrm{C}_{30}$ acceptor atom are negative and positive, respectively. The energy gap of composite 2 is larger than that of composite1; therefore, composite 2 is more stable.

We measured the parameters, such as bond length $(\AA)$, natural bond orbital (NBO) and bond angle (degree), dihedral angle (degree), distances of analysed models, of the single-walled nanotube in this paper, and the end of the nanotube that was saturated by hydrogen atoms in them were examined by DFT at the level of B3LYP and 6-31G (d) standard basis set and shown in Table 2. The DFTcalculated geometric parameters for composite 1 and 2 are compared in Table 2 . The bond lengths $\mathrm{C}_{30}-\mathrm{C}_{84} / \mathrm{O}_{84}$ calculated for composite 1and 2 by the DFT method are 1.47 and $1.37 \AA$, respectively, at the B3LYP/6-31G (d) level. The bond distance of composite 2 decreased toward that of composite 1 because the $\mathrm{O}$ atom in composite 2 is more electronegative than the $\mathrm{C}$ atom.

The bond lengths calculated for $\mathrm{C}_{36}{ }^{\cdots} \mathrm{C}_{29}$ in composite 1 (in the nanotube ring) is $1.44 \AA$ and that in composite 2(in the calixarene ring) is $1.39 \AA$. The bond lengths calculated for $\mathrm{C}_{85}{ }^{\cdots} \mathrm{C}_{87}$ in composite $1,1.37 \AA$ and that in composite 2 is $1.36 \AA$. The $\mathrm{C}_{88}{ }^{-\cdots} \mathrm{N}_{92}$ bond length is lower than the $\mathrm{C}_{36}{ }^{\cdots} \mathrm{C}_{29}$ bond length in compositeland 2 . That is because nitrogen is more electronegative nitrogen than carbon.
Table 2 The parameters of bond and angles propertie in B3LYP/6-31G(d) method for composites at 298.15 K

\begin{tabular}{|c|c|c|}
\hline Agent & Composite 1 & Composite 2 \\
\hline \multicolumn{3}{|l|}{ Bond length $(\AA)$} \\
\hline $\mathrm{C}_{30}-\mathrm{C}_{84} / \mathrm{O}_{84}$ & 1.47 & 1.37 \\
\hline$C_{30}=C_{20}$ & 1.37 & 1.39 \\
\hline $\mathrm{C}_{36} \cdots \mathrm{C}_{29}$ & 1.43 & 1.39 \\
\hline$C_{28}-C_{30}$ & 1.47 & 1.51 \\
\hline $\mathrm{C}_{85} \cdots \mathrm{C}_{87}$ & 1.37 & 1.36 \\
\hline $\mathrm{N}_{87}-\mathrm{C}_{91}$ & 1.39 & 1.38 \\
\hline $\mathrm{C}_{91}=\mathrm{O}_{94}$ & 1.22 & 1.21 \\
\hline \multicolumn{3}{|l|}{ Bond angles (degree) } \\
\hline $\mathrm{C} / \mathrm{S}_{30}-\mathrm{C}_{28}-\mathrm{C}_{27}$ & 116.02 & 118.56 \\
\hline $\mathrm{C}_{84}=\mathrm{C}_{85}-\mathrm{H}_{88}$ & 121.36 & 121.65 \\
\hline $\mathrm{C}_{85} \stackrel{\cdots}{-} \mathrm{N}_{87}-\mathrm{H}_{92}$ & 120.82 & 120.99 \\
\hline $\mathrm{N}_{87}-\mathrm{C}_{91}=\mathrm{O}_{94}$ & 123.42 & 124.32 \\
\hline $\mathrm{C}_{91}-\mathrm{N}_{89}-\mathrm{H}_{93}$ & 115.60 & 114.99 \\
\hline $\mathrm{O}_{90}=\mathrm{C}_{86}-\mathrm{C}_{84}$ & 126.90 & 123.98 \\
\hline \multicolumn{3}{|l|}{ Dihedral angles (degree) } \\
\hline $\mathrm{C}_{30}-\mathrm{C}_{84}=\mathrm{C}_{85} \cdots \mathrm{N}_{87}{ }^{1}$ & 178.86 & -0.063 \\
\hline $\mathrm{H}_{87}-\mathrm{C}_{84}-\mathrm{N}_{86} \cdots \mathrm{H}_{91}{ }^{2}$ & 0.79 & -0.37 \\
\hline $\mathrm{C}_{90}-\mathrm{N}_{88}-\mathrm{C}_{85}=\mathrm{O}_{89}{ }^{3}$ & -178.64 & -178.95 \\
\hline $\mathrm{H}_{61}-\mathrm{C}_{29}=\mathrm{C}_{30}-\mathrm{C}_{28}{ }^{4}$ & 172.74 & -179.95 \\
\hline $\mathrm{O}_{94}=\mathrm{C}_{91}-\mathrm{N}_{89}-\mathrm{C}_{86}{ }^{5}$ & 179.16 & -178.95 \\
\hline $\mathrm{C} / \mathrm{H}_{30}-\mathrm{C}_{28} \cdots \mathrm{C}_{27} \cdots \mathrm{C}_{34}{ }^{6}$ & -26.01 & -178.72 \\
\hline
\end{tabular}




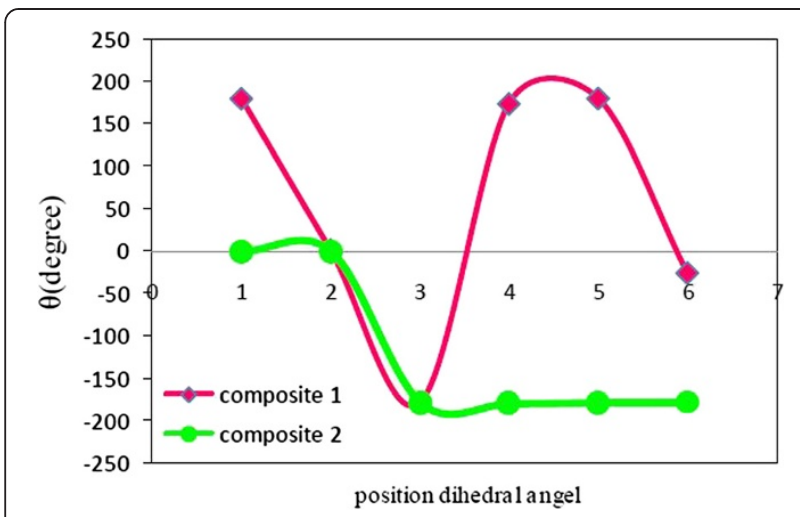

Figure 2 Pole of dihedral angel changes of composites 1 and 2 in b3lyp/6-31G (d) method at $298.15 \mathrm{~K}$. Position 1: $\mathrm{C}_{30}-\mathrm{C}_{84}=\mathrm{C}_{85}$ ${ }_{-} \mathrm{N}_{87}$, position 2: $\mathrm{H}_{87}-\mathrm{C}_{84}-\mathrm{N}_{86} \cdots \mathrm{H}_{91}$, position 3: $\mathrm{C}_{90}-\mathrm{N}_{88}-\mathrm{C}_{85}=\mathrm{O}_{89}$, position 4: $\mathrm{H}_{61}-\mathrm{C}_{29}=\mathrm{C}_{30}-\mathrm{C}_{28}$, position 5: $\mathrm{O}_{94}=\mathrm{C}_{91}-\mathrm{N}_{89}-\mathrm{C}_{86}$, position 6: $\mathrm{C} / \mathrm{H}_{30}-\mathrm{C}_{28} \cdots \mathrm{C}_{27} \cdots \mathrm{C}_{34}$.

The bond angle of $\mathrm{N}_{87}-\mathrm{C}_{91}=\mathrm{O}_{94}$ are $123.41^{\circ}$ and $124.32^{\circ}$ for composites 1 and 2 , respectively. The bond angles of $\mathrm{O}_{90}=\mathrm{C}_{86}-\mathrm{C}_{84}$ are $126.9^{\circ}$ and $123.9^{\circ}$ for composite 1and 2, respectively. The bond angles $\mathrm{C}_{84}-\mathrm{C}_{86}=$ $\mathrm{O}_{90}$ are higher than those of $\mathrm{N}_{87}-\mathrm{C}_{91}=\mathrm{O}_{94}$ in composite 1 and 2. Thus, the interaction of between nonbonding and bonding pairs on the nitrogen atom of the angle is reduced in $\mathrm{N}_{87}-\mathrm{C}_{91}=\mathrm{O}_{94}$.

The dihedral angels of $\mathrm{C}_{30}{ }^{-} \mathrm{C}_{84}=\mathrm{C}_{85} \cdots \mathrm{N}_{87}$ and $\mathrm{C} / \mathrm{H}_{30}{ }^{-}$ $\mathrm{C}_{28}{ }^{-} \mathrm{C}_{27}{ }^{-} \mathrm{C}_{34}$ for composite 1and 2 are $178.48^{\circ}$ and $-0.06 .99^{\circ}$ (position a), $-26.01^{\circ}$ and $-178.72^{\circ}$ (position $\mathrm{f}$ ), respectively. The different dihedral angel in position $\mathrm{a}, \mathrm{b}$, c, $\mathrm{d}$, e and $\mathrm{f}$, are observed in Table 2 and Figure 2.

The electron that is given by the composites in a reaction should be placed on the highest occupied molecular orbital (HOMO), with those which are captured by the composites must be placed on the lowest unoccupied molecular orbital (LUMO) [36], so the atom on which the HOMO is mainly scattered should be able to separated electrons, while the atom by holding the LUMO should achieve electrons on this basis. The energy gap is usually associated with chemical stability against electronic excitation with a larger value like greater stability [37]. Table 3 shows the HOMO and LUMO energy gaps for two composites. By evaluating HOMO/LUMO energy gaps, it is obvious that if that the gap increase, the composite will become stable; therefore, composite 2 is more stable than composite. But, in composite 2 have $\mathrm{S}$ and $\mathrm{O}$ atoms that including non bonding pair interaction with $\mathrm{C}$ atom fluorouracil, thus gap energies lower than composite 1 .

The results of the present work were obtained by DFT optimization and formation energy $\left(\Delta \mathrm{E}_{f}^{\circ}\right.$ in $\left.\mathrm{KJmol}^{-1}\right) \mathrm{cal}-$ culation at the B3LYP/6-31G $(d)$ level. $\Delta \mathrm{E}_{f}^{\circ}$ is calculated using formula $\sum E_{\text {product }}^{\circ}-\sum E_{\text {reactant }}^{\circ}$ The value of $\Delta \mathrm{E}_{\mathrm{f}}^{\circ}$ in composite land 2 are -13.275 and $-38.892 \mathrm{KJmol}^{-1}$, respectively; therefore, composite 2 has lower formation energy than composite 1 . The energy gap, total energy, $\sum E^{2}$, HOMO and LUMO of composites 1 and 2 were also calculated with B3LYP method and 6-31G $(d)$ basis set. The energy $\left(\mathrm{kJ} \mathrm{mol}^{-1}\right)$ and dipole moments (Debye) indicate the consistency between the two composite calculations in the DFT method. The total energy, the sum of is transitional energy, rotational energy and vibration energy, in B3LYP/6-31G (d) level for composite 1and 2 was calculated. The obtained results are shown in Table 3.

Heat capacity is a measurable physical quantity that specifies the amount of heat required to change the temperature of an object by a given amount. Translation energy, rotation energy, and a combination of the two types of energy in vibration (kinetic and potential) of atoms represent the degrees of freedom of motion which classically contribute to the heat capacity of matter, but loosely bound electrons may also participate. For quantum mechanical reasons, at any given temperature, some of these degrees of freedom may be unavailable, or only partially available, to store thermal energy. Quantum theory can be used to quantitatively predict the specific heat capacity of simple systems.

\section{Conclusions}

In this paper, the results show that the complex of $p$-Sulphonatocalix[4]arene and fluorouracil is more stable than nanotube-fluorouracil. Composite 2 is a better conditioner of drugs than composite 1 . NBO analysis shows larger energy gap in composite2. Composite 2 has lower formation energy, and it is more stable than composite1.

\section{Methods}

The investigation is carried out using a personal computer which has Intel ${ }^{\circledR}$ Pentium ${ }^{\circledR}$ dual CPU with 2-GB RAM. Nanotube-fluorouracil (composite 1) and $p$-Sulphonatocalix

Table 3 Parameters of stability composites are calculated by B3LYP/ 6-31G (d) method at 298.15 K

\begin{tabular}{|c|c|c|c|c|c|c|c|}
\hline Agent & $\begin{array}{l}\mathrm{E}_{\text {total }} \\
\left(\mathrm{KJmol}^{-1}\right)\end{array}$ & $\begin{array}{l}\Delta \mathrm{E}_{f}^{\circ} \\
\left(\mathrm{KJmol}^{-1}\right)\end{array}$ & $\begin{array}{l}\text { HOMO } \\
\left(\mathrm{KJmol}^{-1}\right)\end{array}$ & $\begin{array}{l}\text { LUMO } \\
\left(\mathrm{KJmol}^{-1}\right)\end{array}$ & $\begin{array}{l}\text { Gap } \\
\left(\mathrm{KJmol}^{-1}\right)\end{array}$ & $\begin{array}{l}\mu \\
\text { (Debye) }\end{array}$ & $C_{v}$ \\
\hline Composite 1 & 465.73 & -13.275 & -0.15877 & -0.08918 & -0.0696 & 0.527 & 191.03 \\
\hline Composite 2 & 396.25 & -38.897 & -0.2601 & -0.07261 & -0.18749 & -1.137 & 186.77 \\
\hline
\end{tabular}


[4]arene-fluorouracil (composite 2) included a calixarene derivation (with different atom number) which reacts with the anti-cancer drug. In this paper, drug delivery properties are investigated by NBO analysis and DFT method. DFT calculations have been performed using the nanotube modeler [38] Gaussview [39] and Gaussian 03 [40] by B3LYP method and 6-31G $(d)$ standard basis set. NBO analysis [41] calculations have also been performed for all composites by B3LYP method and 6-31G(d) standard basis set. Then complexes of the calix[n]arenes derivative and single-walled nanotube with fluorouracil are optimized. The bond length $(\AA)$, bond angel (degree), dihedral angel (degree), hyperconjucation energy $\left(E^{2}\right)$, and total energy $\left(E_{t}\right.$ in $\left.\mathrm{KJ} \mathrm{mol}^{-1}\right)$, moment dipole ( $\mu$ in Debye), occupancy, and HOMO/LUMO are investigated in the composites by B3LYP/6-31G $(d)$ method.

The nanotube $\left(\mathrm{C}_{60} \mathrm{H}_{24}\right)$ and $p$-sulphonatocalix[4] arenes $\left(\mathrm{C}_{28} \mathrm{H}_{24} \mathrm{O}_{16} \mathrm{~S}_{4}\right)$ and fluorouracil $\left(\mathrm{C}_{4} \mathrm{H}_{3} \mathrm{FN}_{2} \mathrm{O}_{2}\right)$ are reacted by Equations 1and 2, thus is formed products nanotube- fluorouracil $\left(\mathrm{C}_{64} \mathrm{H}_{26} \mathrm{~N}_{2} \mathrm{O}_{2}\right), p$-sulphonatocalix [4]arenes- fluorouracil $\left(\mathrm{C}_{32} \mathrm{H}_{26} \mathrm{~N}_{2} \mathrm{O}_{18} \mathrm{~S}_{4}\right)$ and $\mathrm{HF}$ in phases gas.

$$
\begin{aligned}
& \mathrm{C}_{4} \mathrm{H}_{3} \mathrm{FN}_{2} \mathrm{O}_{2}+\mathrm{C}_{60} \mathrm{H}_{24} \rightarrow \mathrm{C}_{64} \mathrm{H}_{26} \mathrm{~N}_{2} \mathrm{O}_{2} \\
& + \text { HF (bond C-C) }
\end{aligned}
$$

$$
\begin{aligned}
& \mathrm{C}_{4} \mathrm{H}_{3} \mathrm{FN}_{2} \mathrm{O}_{2}+\mathrm{C}_{28} \mathrm{H}_{24} \mathrm{O}_{16} \mathrm{~S}_{4} \rightarrow \mathrm{C}_{32} \mathrm{H}_{26} \mathrm{~N}_{2} \mathrm{O}_{18} \mathrm{~S}_{4} \\
& + \text { HF (bond C-O) }
\end{aligned}
$$

\section{Competing interests}

The authors declare that they have no competing interests.

\section{Authors' contributions}

KZ and NSH both contributed to this research work. Both authors read and approved the final manuscript.

\section{Acknowledgements}

Both of authors are grateful to University of Science and Research Branch, Islamic Azad University, Tehran, Iran. We are grateful to Shahid Beheshti University, Tehran, Iran. We are grateful to Young Researchers and Elites Club, Rasht Branch, Islamic Azad University, Rasht, Iran for financial support.

\section{Author details}

'Department of Chemistry, Science and Research Branch, Islamic Azad University, Tehran, Iran. ${ }^{2}$ Department of Chemistry, Shahid Beheshti University, Evin, Tehran, Iran. ${ }^{3}$ Young Researchers and Elites Club, Rasht Branch, Islamic Azad University, Rasht, Iran.

Received: 9 June 2013 Accepted: 11 July 2013

\section{References}

1. lijima, S: Helical microtubules of graphitic carbon. Nature 354, 56-58 (1991)

2. Colomer, JF, Henrard, L, Lambin, P, Van Tendeloo 1, G: Electron diffraction study of small bundles of single-wall carbon nanotubes with unique helicity. Phys Rev B 64, 1-7 (2001)

3. S Berber, S, Kwon, YK, Tom'anek, D: Unusually high thermal conductivity of carbon nanotubes. Phys. Rev. Lett 84, 4613-4616 (2000)

4. Singh, R, Pantarotto, D, Lacerda, L, Pastorin, G, Klumpp, C, Prato, M, Bianco, A, Kostarelos, K: Tissue biodistribution and blood clearance rates of intravenously administered carbon nanotube radiotracers. Proc Natl Acad Sci USA 103, 3357-3362 (2006)

5. White, CT, Todorov, TN: Carbon nanotubes as long ballistic conductors. Nature 393, 240-241 (1998)
6. Taft, BJ, Lazareck, AD, Withey, GD, Yin, A, Xu, JM, Kelley, SO: Site-specific assembly of DNA and appended cargo on arrayed carbon nanotubes. J. Am. Chem. Soc. 126, 12750-12751 (2004)

7. Wong Shi Kam, N, Jessop, TC, Wender, PA, Dai, H: Nanotube molecular transporters: internalization of carbon nanotube-protein conjugates into mammalian cells. J. Am. Chem. Soc. 126, 6850-6851 (2004)

8. Pantarotto, D, Singh, R, McCarthy, D, Erhardt, M, Briand, JP, Prato, M, Kostarelos, K, Bianco, A: Functionalized carbon nanotubes for plasmid DNA gene delivery. Angew. Chem., Int. Ed. 43, 5236-5242 (2004)

9. Petersen, JL, Egan, DM: Small security: nanotechnology and future defense. Defense Horizons 8, 1-6 (2002)

10. Zhdanov, VP, Kasemo, B: Simulations of the reaction kinetics on nanometer supported catalyst particles. Surf. Sci. Rep. 39, 25-104 (2000)

11. Gutsche, CD, Bauer, LJ: The conformational properties of calix[4]arenes, calix[6]arenes, calix[8]arenes, and oxacalixarenes. J. Am. Chem. Soc. $107,6052-6059(1985)$

12. Gungor, O, Memon, S, Yilmaz, M: Synthesis of alkyl nitrile and alkyl benzonitrile derivatives of calix[4]arene and their polymer supported analogues: a comparative study in two-phase extraction systems. J. Funct. Polym 63, 1-9 (2005)

13. Asfari, Z, Böhmer, V, Harrowfield, J, Vicens, J: Calixarenes. ED; Kluwer, Dordrecht (2001)

14. Faraji, M, Zare, K, Aghaei, H, Farajtabar, A, Asfari, Z, Gharib, F: Complexation of p-Sulphonato-calix[6]arene by Glycine, Glycyl-glycine, and Glycyl-glycyl -glycine in Aqueous Solution. J. Solution Chem. 41, 2074-2081 (2012)

15. Gharib, F, Zare, K, Taghvaei, S, Monajjemi, M, Amiri, A: Complexation of tri-o -propoyl-p-t-butyl calix[4]arene with alkali metal cations in carbon tetrachloride solvent. Main Group Met. Chem. 26, 255-258 (2003)

16. Gharib, F, Zare, K, Amiri, A: Spectrophotometric studies of alkali metal ion complexes of p-tetrabutyl- calix[4]arenes. Russ. J. Inorg. Chem. 49, 1511-1514 (2004)

17. Gharib, F, Osouleddini, N, Zare, K, Taghvaei-Ganjali, S: Spectrophotometric studies of alkali and alkali earth metal ions complexes of mono amino derivative of calix[4]arene. Russ. J. Inorg. Chem. 55, 434-437 (2010)

18. Brunink, JAJ, Verboom, W, Engbersen, JFJ, Reinhoudt, DN, Harkema, S: Synthesis and cation complexation selectivity of bis(syn-proximally) functionalized calix[4]arenes. Recl. Trav. Chim. Pays-Bas 111, 511-516 (1992)

19. Shirakawa, S, Shimizu, S: Dehydrative amination of alcohols in water using a water-soluble calix[4]resorcinarene sulfonic acid. Syn. lett 10, 1539-1542 (2008)

20. Liu, YL, Liu, L, Wang, YL, Han, YC, Wang, D, Chen, YJ: Calix[n]arene sulfonic acids bearing pendant aliphatic chains as recyclable surfactant-type Brønsted acid catalysts for allylic alkylation with allyl alcohols in water. Green Chem. 10, 635-640 (2008)

21. Zhang, YJ, Cao, WX, Xu: Interaction of sulfonated calix[n]arenes with Rhodamine $B$ and its application to determine acetylcholine in a real neutral aqueous medium J. Chin. Chem 20, 322-326 (2002)

22. Guo, D, Liu, Y: Calixarene-based supramolecular polymerization in solution. Chem. Soc. Rev. 41, 5907-5921 (2012)

23. Dalili, N, Zare, K, Gharib, F, Shadmani, N: Calixarenes or nanotubes: which are better in drug delivery? JNSC 2, 213-217 (2011)

24. Dings, RP, Miller, MC, Nesmelova, I, Astorgues-Xerri, L, Kumar, N, Serova, M, Chen, X, Raymond, E, Hoye, TR, Mayo, KH: Antitumor agent calixarene 0118 targets human galectin-1 as an allosteric inhibitor of carbohydrate binding. J. Med. Chem. 14, 5121-5129 (2012)

25. Fátima, AD, Fernandes, SA, Sabino, AA: Calixarenes as new platforms for drug design. Curr. Drug Discovery Technol. 6, 1-20 (2009)

26. Moore, MJ, Erichman, C, Kaizer, L, Fine, S: A phase II study of 5-fluorouracil, leucovorin and interferon alpha in advanced pancreatic cancer. Anticancer Drugs 4, 555-557 (1993)

27. Cornell, GN, Cahow, CE, Frey, C, McSherry, C, Beal, JM: Clinical experience with 5-fluorouracil (NSC-19 893) in the treatment of malignant disease. Cancer Chemother Rep 9, 23-30 (1960)

28. Jemal, A, Murray, T, Samuels, A, Ghafoor, A, Ward, E, Thun, MJ: Cancer statistics. CA A Cancer Journal for Clinicians 53, 5-26 (2003). 2003

29. Fernandez, L, Viruela-Martin, P, Latorre, J, Guillem, C, Beltrán, A, Amorós, P: Molecular precursors of mesostructured silica materials in the atrane route: a DFT/GIAO/NBO theoretical study. J. Mol. Stru: THEOCHEM 822, 89-102 (2007)

30. Monajjemi, M, Chahkandi., B, Zare, K, Amiri, A: Study of the hydrogen bond in different orientations of adenine-thymine base pairs: an ab initio study. Biochemistry 70, 366-376 (2005) 
31. Tirado-Rives, J, Jorgensen, WL: Performance of B3LYP density functional methods for a large set of organic molecules. J. Chem. Theory Comput. 4, 297-306 (2008)

32. Zeevaart, JG, Wang, L, Thakur, W, Leung, CS, Tirado-Rives, J, Bailey, CM, Domaoal, RA, Anderson, KS, Jorgensen, WL: Optimization of azoles as antihuman immunodeficiency virus agents guided by free-energy calculations. J. Am. Chem. Soc. 130, 9492-9499 (2008)

33. Dolg, M: Recent progress in understanding chemical shifts. J. Chem. Phys. 115, 7348-7355 (2009)

34. Basilio, N, Francisco, V, Garcia-Rio, L: Aggregation of $p$-Sulfonatocalixarenebased amphiphiles and supra-amphiphiles. Int. J. Mol. Sci 14, 3140-3157 (2013)

35. Casabianca, LB, Kallgren, JB, Natarajan, JK, Alumasa, JN, Roepe, PD, Wolf, C, de Dios, AC: Antimalarial drugs and heme in detergent micelles: an NMR study. Inorg. J. Biochem 103, 745-748 (2009)

36. Abul Haider Shipar, M: DFT studies on fructose and Glycine Maillard reaction: formation of the Heyns rearrangement products in the initial stage. J Iran Chem Soc 8, 433-448 (2011)

37. Vassil, B: Delchev: Computational (DFT and TD DFT) study of the electron structure of the tautomers / conformers of uridine and deoxyuridine and the processes of intramolecular proton transfers. J Mol Model 16, 749-757 (2010)

38. Nanotube Modeler. version 1.2.4 (2004-2005).. www.jcrystal.com/products/ wincnt/Nanotube

39. Frisch, A, Nielsen, AB, Holder, AJ: GaussView User Manual. Gaussian Inc., Wallingford (2000)

40. Frisch, MJ, Trucks, GW, Schlegel, HB, Scuseria, GE, Robb, MA, Cheeseman, JR, Zakrzewski, VG, Montgomery, JA, Stratmann, RE, Burant, JC, Dapprich, S, Millam, JM, Daniels, AD, Kudin, KN, Strain, MC, Farkas, O, Tomasi, J, Barone, V, Cossi, M, Cammi, R, Mennucci, B, Pomelli, C, Adamo, C, Clifford, S, Ochterski, J, Petersson, GA, Ayala, PY, Cui, Q, Morokuma, K, Malick, DK, Rabuck, AD, Raghavachari, K, Foresman, JB, Cioslowski, J, Ortiz, JV, Baboul, AG, Stefanov, BB, Liu, G, Liashenko, A, Piskorz, P, Komaromi, I, Gomperts, R, Martin, RL, Fox, DJ, Keith, T, Al-Laham, MA, Peng, CY, Nanayakkara, A, Gonzalez, C, Challacombe, M, Gill, PMW, Johnson, B, Chen, W, Wong, MW, Andres, JL, Gonzalez, C, Head Gordon, M, Replogle, ES, Pople, JA: GAUSSIAN 03, revision B.02. Gaussian Inc, Pittsburgh, PA (2003)

41. Glendening, ED, Reed, AE, Carpenter, JE, Weinhold, F: NBO version 3.1. Gaussian Inc, Pittsburg, PA (2003)

10.1186/2193-8865-3-72

Cite this article as: Zare and Shadmani: Comparison of drug delivery systems: Nanotube and $p$ - Sulphonatocalix[4]arene, by Density

Functional Theory. Journal Of Nanostructure in Chemistry 2013, 3:72

\section{Submit your manuscript to a SpringerOpen ${ }^{\circ}$ journal and benefit from:}

- Convenient online submission

$\checkmark$ Rigorous peer review

- Immediate publication on acceptance

- Open access: articles freely available online

- High visibility within the field

- Retaining the copyright to your article

Submit your next manuscript at $>$ springeropen.com 